\title{
三峡工程中的生物多样性保护
}

\author{
黄真理 ${ }^{12}$ \\ 1 (中科院水生生物研究所, 武汉 430072) \\ 2 ( 国务院三峡工程建设委员会办公室, 北京 100038)
}

摘要: 三峡工程导致长江水文情势改变、水库淹没和移民搬迁, 成为影响生物多样性的直接的、主要的因素。本文 根据最新调查和研究成果, 评述了三峡工程对生物多样性的影响, 介绍了正在采取的措施及其效果。水库淹没和 移民搬迁是影响陆生生物的主要因素。三峡库区有 144 个植物群系, 6388 种高等植物, 3418 种昆虫, 500 种陆生脊 椎动物。其中 36 个植物群系受到部分或全部淹没影响, 4 种地方特有植物的野生种群遭到淹没 ( 1 种全淹, 3 种部 分淹没)。水文情势改变是影响水生生物的主要因素。长江水系共有鱼类 350 种, 浮游动植物、底栖动物、水生植 物等 1085 种。其中,三峡工程对部分珍稀大型水生动物、40 余种特有鱼类和 四大家鱼”的影响值得重视。我们将 通过建立长期的生物监测站、设立保护区和保护点、采用人工繁殖放流等措施保护生物多样性,减少三峡工程对生 物多样性的不利影响，避免因三峡工程而造成物种丧失。

关键词:三峡工程, 生物多样性, 保护区,人工繁殖放流,生态环境监测网络

中图分类号: Q16, X176 文献标识码 : B 文章编号 : 1005-0094(2001)04-0472-10

\section{Biodiversity conservation for the Three Gorges Project}

HUANG Zhen- $\mathrm{Li}^{1}{ }^{2}$

1 Institute of Hydrobiology , Chinese Academy of Sciences , Wuhan 430072

2 Executive Office of the State Council Three Gorges Project Construction Committee , Beijing 100038

Abstract : The Three Gorges Project ( TGP) ,now under construction, will cause hydrological variation of Yangtze River. Reservoir inundation and large amounts of resettlement of people are direct and key factors affecting biodiversity conservation of the affected area. Based on the latest field investigations and research findings, this paper reviews the related issues on biodiversity conservation of TGP. For the Three Gorges reservoir area , there are 144 vegetation types ,6388 high plant species , 3418 insect species , and 500 terrestrial vertebrate species. The reservoir inundation and resettlement are major factors affecting terrestrial life, in which 36 vegetation types will be affected and four endemic plant species will be submerged (one species range fully submerged and three species partly). There are 350 fish species and 1085 aquatic species including plankton, benthic and aquatic plants in Yangtze River which are mainly affected by the hydrological variation. Some endemic or endangered aquatic lives , such as Chinese River Dolphin , Chinese Finless Porpoise, Chinese sturgeon, Chinese Paddlefish, Dabry Sturgeon , Chinese Sucker and four fish species (Black Carp , Grass Carp , Silver Carp and Bighead) , are worth paying more attention to. The populations of these species have already sharply decreased due to non-Three Gorges Project factors. With the construction of TGP , many countermeasures will be taken, such as setting up a long-term ecological and environmental monitoring network, setting up nature reserves for conservation priorities, and implementing artificial breeding and stocking for the endangered fishes , to reduce negative impacts on biodiversity and thereby to assure no loss of species from the TGP.

Key words : Three Gorges Project, biodiversity, nature reserve , artificial breeding and stocking , ecological and environmental monitoring network 


\section{1 前言}

三峡工程是目前世界上在建的最大水利枢纽工 程, 也是治理和开发长江的关键性骨干工程, 具有防 洪、发电、航运等巨大的综合效益。但与此同时, 它 可能引起的生态与环境问题也受到国内外广泛关 注。在一个人类活动频繁、经济落后、生态脆弱而又 进行快速经济建设的三峡地区, 影响生态环境的因 素十分复杂，工程与非工程影响交织。直接与间接 影响交织,在众多的影响因素中, 要对工程的影响进 行定量、准确的分析和预报往往很难，如何进行生态 监测也缺乏完整的指标体系。

本文从工程对生态环境影响的主要诱因出发, 分析其主要影响范围和区域，根据最新的调查和监 测资料，综合三峡工程影响区的生物多样性现状，分 析其对生物多样性的影响，并对有关保护措施进行 介绍和评价。

\section{1 主要诱因}

要研究三峡工程对生物多样性的影响,首先要 知道修建水库是如何影响生态环境的, 即了解导致 生态环境改变的诱因。一般说来,水库对生态环境 的影响主要表现在三个方面:(1) 库区和坝下游水 文情势的改变。由于水库的调节作用,改变了库区 及坝下游的天然的水文情势，如水位、流量、含沙量、 蒸发量、水温等等。水位的上升带来了淹没，危及淹 没区的物种安全。大坝的拦截，把天然情况下上、下 游水生动物的双向交流切断，或者只有上游向下游 的单向传输; (2) 移民带来的影响。主要是移民迁 建区的人类活动和土地利用变化的影响; (3) 施工 区的影响。由于施工区的范围相对较小 (如三峡工 程施工区面积为 $15.28 \mathrm{~km}^{2}$ ) ,对生态环境的影响是 局部性的。

因此, 水库对生态环境的直接影响主要是导致 水文情势的改变和移民搬迁。间接影响包括由于建 成后自然环境和社会环境的改变间接引起生态环境 的改变,如局地气候的变化会间接地导致某些生物 群落结构发生变化。

\subsection{1 库区和坝下游水文情势的改变 三峡工程} 坝址位于湖北省宜昌市三斗坪镇，在葛洲坝上游约 $40 \mathrm{~km}$ 处。正常蓄水位 $175 \mathrm{~m}$ (吴淞高程,下同) , 汛 期 20 年一遇洪水的回水末端在重庆巴县弹子田, 距 坝址约 $580 \mathrm{~km}$ 。水库面积约 $1080 \mathrm{~km}^{2}$, 水面平均宽 $1100 \mathrm{~m}$ (比天然情况增加一倍)。由于三峡地区的
特殊地形地貌, 断面窄深, 保持狭长的条带河道形 状, 属典型河道型水库。坝址处多年平均流量为 4510 亿 $\mathrm{m}^{3}$, 而水库的总库容为 393 亿 $\mathrm{m}^{3}$, 其中调节 库容为 165 亿 $\mathrm{m}^{3}$ 约占坝址年径流量的 $3.7 \%$,库水 交换频繁, 属于季调节水库, 这与多年调节的埃及 ASWAN 高坝不同。一般说来, 库容系数越大, 水库 控制径流能力越强, 对环境的影响越大( 黄真理, 2001 )。

三峡水库的最终运行方式为:每年 5 月末 6 月 初, 水库水位降至 $145 \mathrm{~m}$ 运行, 以满足防洪要求。10 月份后开始蓄水, 水位逐步抬高到 $175 \mathrm{~m}$ 。从 11 月 份至次年 4 月底, 水库在 $175 \mathrm{~m}$ 的高水位运行。对 坝下游来说, 每年汛期水库在低水位 $145 \mathrm{~m}$ 运行时, 下泄流量与天然情况相同。10月份水库蓄水时，下 泄流量减少。枯水季节 $1 \sim 5$ 月份, 根据发电和航运 要求, 下泄流量增加 $1000 \sim 2000 \mathrm{~m}^{3} / \mathrm{s}$ 。成库后, 库 区局地气候、水质、水温、环境地质等自然环境因子 发生一定变化 (中国科学院环境评价部, 长江水资 源保护科研所,1996)。

1.1.2 移民三峡水库淹没陆地面积 $632 \mathrm{~km}^{2}$ 。 根据 1991 年 1992 年调查复核, 主要淹没指标为 : 直接淹没人口 84.26 万人, 其中农业人口 36.15 万 人淹没耕地 $172 \mathrm{~km}^{2}$, 园地 $73 \mathrm{~km}^{2}$, 河滩地 $39 \mathrm{~km}^{2}$; 受淹城镇 13 个, 集镇 114 个, 工矿企业 1599 个 (中 国科学院环境评价部，长江水资源保护科研所， $1996)$ 。根据移民安置规划计算, 规划搬迁年的移 民将达到 113 万人, 这数量巨大的移民大多数将主 要依靠就地后靠安置。

三峡库区是一个特定的地域概念, 是指水库淹 没区和就地后靠移民安置区所涉及的 19 个行政县 (市) 区域。据 1999 年最新统计 (国家环境保护总 局，1997 2000), 库区总人口 1954.53 万人, 其中 农业人口 1467.1 万人。总面积 5.8 万 $\mathrm{km}^{2}$, 其中耕 地面积 0.96 万 $\mathrm{km}^{2}$, 人均耕地 $0.0653 \mathrm{hm}^{2}(0.98$ 亩)。也就是说, 113 万的移民将主要由 5.8 万 $\mathrm{km}^{2}$ 的库区吸纳解决。

\section{2 主要影响区}

诱因和影响范围不清,环境影响评价结论就不 正确。通过以上诱因分析可以明确, 三峡工程对陆 生生物的影响, 主要是由水库淹没和移民搬迁引起 的,主要影响区域为淹没区(占库区总面积的 $1.1 \%)$ 和移民安置区, 仅为库区总面积的很小部 
分。很多学者在评价三峡工程对陆生生物的影响 时,常常把行政管理意义上的库区面积当作影响区 面积, 这是错误的。对水生生物的影响, 主要是由水 库蓄水后水文情势的改变引起的, 涉及的范围较大， 宏观上可以认为从水库库尾到河口及近海区域, 包 括受淹的支流。

\section{2 三峡工程对生物多样性的影响分析}

\section{1 陆生生物}

三峡库区的历史遗迹有丰富的文化底蕴, 最早 可上溯到 10 万 1 万年前的旧石器时代。夏商时 期这里就分布着属于巴文化系统的若干部落集团或 邦国 ${ }^{1}$ 。北魏地理学家郘道元 (466 或 $472 \sim 527$ 年) 和唐代诗人李白 (701 762 年) 等人关于 猿啼” 的 大量记录和文学描述，反映了 1200 多年前三峡地区 森林茂盛,有长臂猿存在。1986 年在巫山太平村附 近发现一件长臂猿骨骼及牙化石，经测定下牙床化 石所在的地层距今约 290 年。这表明直至清康熙年 间,三峡库区的森林植被仍然较好, 还有长臂猿出没 其间 ${ }^{2}$ 。据记载, 在 18、19 世纪,三峡库区还分布有 大熊猫(蒋志刚等,1997)。

经过长期人类活动的影响,自然生态破坏严重， 生态系统脆弱。人口的增加导致人均耕地面积少， 土地承载压力大。目前库区的植被面貌发生了很大 的变化, 除边缘高山区外, 原始植被所存极少, 大片 分布的是马尾松疏林、柏木疏林及各类灌丛或草丛， 农业植被也占有很大比重。森林覆盖率, 在重庆库 区为 $22 \%$ ，湖北库区为 $32 \%$ 。江岸两侧海拔 $800 \mathrm{~m}$ 以下地区已很少有森林存在，绝大部分是梯田和坡 耕地。库区的陆生动物也由以森林为栖息地的类型 演变为以灌草丛为栖息地的类型。珍稀的陆生野生 动物只有在海拔高、森林植被好的地区才有分布。

2.1.1 植被和植物 三峡库区植被类型在 70 个以 上,其中乔木类型 25 个以上,分布海拔为 $180 \sim$ $1810 \mathrm{~m}$;灌木类型 16 个以上,分布海拔为 $110 \sim$ $1900 \mathrm{~m}$; 草本共 22 个类型。除农作物和一些经济林 外,库区共有 144 个植物群系,其中基本分布在 175 $\mathrm{m}$ 以下的有 20 个群系, 部分分布在 $175 \mathrm{~m}$ 以下的有 16 个群系, 移民迁建区范围内约有 71 个群系。通 过对沿江 17 条海拔 $200 \mathrm{~m}$ 以下样带的调查 :长江沿 岸 $200 \mathrm{~m}$ 以下森林很少, 主要为灌丛和草本群落。 库区受淹的植被类型为 27 个。只有疏花水柏枝
(Myricaria laxiflora) 灌丛、巫溪叶底珠 (Securinega wuxiensis) 灌丛、荷叶铁线蕨(Adiantum reniforme var. sinensis) 草丛和巫山类芦 (Neyraudia wushanica) 草 丛是受淹没影响的库区特有的群落类型。在宜昌、 兴山一带 $1000 \mathrm{~m}$ 以上的高山峻岭中还存在着少量 的原始植物群落, 也是重要的珍稀物种的分布地。 但在三峡工程可能影响的低海拔地区已没有反映原 始植被面貌的完整的地带性植被( 陈伟烈等, 1994 )。

表 1 三峡库区植物的物种组成 (1999 年)

Table 1 Species composition of plant in the Three Gorges Reservoir area (Survey results in 1999)

\begin{tabular}{|c|c|c|c|c|}
\hline \multicolumn{2}{|c|}{$\begin{array}{c}\text { 植物类型 } \\
\text { Category of plant }\end{array}$} & $\begin{array}{c}\text { 科 } \\
\text { Family }\end{array}$ & $\begin{array}{c}\text { 属 } \\
\text { Genera }\end{array}$ & $\begin{array}{c}\text { 种和种以下 } \\
\text { Species and } \\
\text { below }\end{array}$ \\
\hline \multicolumn{2}{|c|}{ 苔蘚植物 Bryophyte } & 29 & 60 & 120 \\
\hline \multicolumn{2}{|c|}{ 蕨类植物 Fern } & 38 & 227 & 400 \\
\hline \multicolumn{2}{|c|}{ 裸子植物 Gymnosperm } & 9 & 34 & 88 \\
\hline \multirow{2}{*}{$\begin{array}{c}\text { 被子植物 } \\
\text { Angiosperm }\end{array}$} & $\begin{array}{c}\text { 双子叶 } \\
\text { Dicotyledoneae }\end{array}$ & 142 & 1020 & 4610 \\
\hline & $\begin{array}{c}\text { 单子叶 } \\
\text { Monocotyledoneae }\end{array}$ & 20 & 298 & 1100 \\
\hline 总计 Total & & 238 & 1508 & 6388 \\
\hline
\end{tabular}

表 1 所示 1999 年本底调查结果表明,三峡库区 的高等植物有 6388 种 (包括亚种、变种、变型) (国 家环境保护总局,1997 2000; 肖文发等,2000)。 三峡库区独特的地理条件使该地区未遭受第四纪冰 川的严重袭击,成为珍稀濒危植物的避难所。目前, 三峡库区列入国家保护植物名录的有 155 种, 库区 特有植物 54 种。很多是我国特有、稀有和珍贵的古 老子遗树种，如珙桐 (Davidia involucrata)、银杉 (Cathaya argyrophylla)、水杉 (Metasequoia glyptostroboides)、连香树 (Cercidiphyllum japonicum)、鹅 掌楸 (Liriodendron chinense)、铁坚杉 (Keteleeria davidiana)、檫木 (Sassafras tzumu)、水青树（Tetracentron sinensis) 等。

综合最新调查研究成果, 可以确定受三峡工程 淹没影响、应重点保护的珍稀特有物种是: 疏花水柏 枝、荷叶铁线彍、巫山类芦和巫溪叶底珠 (后两个物 种尚未正式发表)。疏花水柏枝为库区特有灌木,

(1)三峡工程库区文物保护规划组, 1996 年 3 月。《长江三峡工程淹 没及迁建区文物古迹保护规划报告》

(2)李斌, 1998 年 4 月 10 日, 三峡周报. 我国科学家破解三峡啼猿” 之谜 
分布于三峡河谷两岸 $80 \sim 130 \mathrm{~m}$ 高程范围内的砾 质、沙质或石质河滩地中。根据目前调查结果, 疏花 水柏枝是三峡工程唯一全部被淹没的植物 ${ }^{\mathbb{1} 2}$ 。荷 叶铁线蓱为我国二级保护植物，属库区特有种，具有 观赏和药用价值, 该种与大西洋亚速尔群岛上的肾 叶铁线偋 (Adiantum reniforme) 有亲缘关系,主产于 重庆万州区和石柱县的长江边上, 主要分布在海拔 $170 \mathrm{~m} \pm 30 \mathrm{~m}$ 的范围内, 部分受淹没影响( 谢宗强, 马克平,1998)。巫山类芦和巫溪叶底珠的垂直分 布范围高达 $400 \mathrm{~m}$,少部分受淹没影响。川明参 (Chuanminshen violaceum) 不是库区特有植物，人工 栽培较多,在四川、重庆、湖北都有分布。在三峡库 区, 星散状分布于䄰归、宜昌和万县的 $80 \sim 380 \mathrm{~m}$ 高 程范围内, 仅受部分淹没影响, 更不会危及物种安 全。因此，笔者认为不宜把它列为三峡工程重点保 护的植物物种。从 1996 年起，我们组织对库区陆生 动植物背景情况进行了全面调查，发现了在淹没线 $175 \mathrm{~m}$ 水位以上的荷叶铁线䓲、巫溪叶底珠、川明参 及其群落的新分布点以及海拔 $1000 \mathrm{~m}$ 以上一批珍 稀树种的野生分布。其中，在万州五桥(海拔 240 $\mathrm{m}$ ) 和石柱县 (海拔 $260 \sim 280 \mathrm{~m}$ ) 的长江边分别发现 $20 \mathrm{hm}^{2}$ 和 $1000 \mathrm{~m}^{2}$ 分布范围的荷叶铁线偋群落; 在 巴东官渡镇长江两岸海拔 $400 \mathrm{~m}$ 高程以下的砂岩上 发现 $2 \mathrm{~km}^{2}$ 分布范围的巫溪叶底珠群落; 在䄰归茅 坪镇发现新的川明参及其群落。这对三峡水库建成 后, 这些物种野生种群的生存和物种安全具有重要 意义。连续 5 年的调查表明, 尚未发现有新的、受重 大影响的珍稀或库区特有植物物种。

目前已调查到库区内百年以上古树 4514 棵, 共 157 种。其中列入国家保护名录的树种有 12 种。 这些古树中, 受淹没影响的数量仅为 29 株, 多数为 在江边生长的非珍贵树种, 分布在䄰归 (11 株)、奉 节 (6 株)、宜昌 (5 株)、巫山 (3 株)、巴东 ( 2 株)、云 阳 ( 2 株) 共 6 个县。 $175 \mathrm{~m}$ 淹没水位以上的古树, 大部分分布在 $800 \mathrm{~m}$ 以上的高海拔地区，不会受到 影响。少部分分布在移民安置区，如不保护可能会 受到移民搬迁的影响（肖文发等，2000）。

三峡库区共有资源植物 10 大类, 2021 种。其 中，药用植物共有 1129 种，在 $200 \mathrm{~m}$ 以下有分布的 种类约占 $15.32 \%$ 。水库蓄水后,有些资源植物的 生境将受少量淹没，造成一定的资源损失，但对资源 的利用影响不大(谢宗强，陈伟烈，1999）。
2.1.2 动物 据 1993 1995 年的调查:三峡库区 有昆虫纲 19 目 242 科 1940 属 3418 种, 其中新属 16 个, 新种 289 个, 新记录属 16 个, 新记录种 94 个(杨 星科, 1997)。库区还有蛛形纲 2 目 23 科 44 属 67 种, 其中新记录种 2 个。库区昆虫以东亚成份为主, 据不完全统计所占比例高达库区昆虫总数的 $57.2 \%$ 。在分布特征上具有优势种明显、东西差异显 著、垂直带简单等特点。22 个采样点的多样性分析 表明:三峡库区的昆虫多样性指数 (Margalef 物种丰 富度指数和 Shannon-Wiener 指数) 的高值出现在高 海拔地区林相复杂的森林生态系统, 而低海拔地区 如淹没线附近 $(175 \mathrm{~m})$ 的农田、灌丛、河滩、湿地等 生态系统的物种多样性指数较低。因此,三峡工程 对昆虫多样性指数高的地区没有直接影响。应该指 出, 由于昆虫在群落中处于较低的营养层次, 对环境 变化的敏感性较高。

最新研究表明:三峡库区陆生脊椎动物共 500 种 (实际调查发现 411 种, 文献记录 89 种), 包括兽 类 101 种，鸟类 319 种,爬行类 35 种，两栖类 32 种。 其中属国家一类保护动物的兽类 4 种，鸟类 3 种; 属 国家二类保护动物的兽类 16 种，鸟类 35 种, 两栖类 1 种。由于库区的重要野生动物主要分布在 $1300 \mathrm{~m}$ 以上的高海拔地区, 因此, 三峡工程本身不构成对库 区重要陆生野生动物的直接影响。对三峡库区野生 动物特别是珍稀物种威胁最大的是人类活动, 特别 是木材砍伐、狩猎和栖息地的丧失等，其威胁程度远 远大于三峡工程本身的直接影响（肖文发等， 2000 )。

\section{2 水生生物}

\subsection{1 浮游动植物、底栖动物及水生植物}

长江及附属湖泊的浮游植物有 8 门 183 属 321 种。其中绿藻的种类最多, 其次为矽藻和蓝藻。长 江水系浮游植物常见种约 100 种, 优势种随生境和 季节而变化, 数量上有上游向下游递减的分布趋势 (长江水系渔业资源调查协作组, 1990)。三峡库区 有藻类植物 80 余属, 种类以硅藻和绿藻居多, 干流 中着生藻类少, 支流中种类丰富。长江干支流及重 点湖泊的浮游动物有 154 属 330 多种, 其中: 原生动

(1)中科院武汉植物所, 2001 年 4 月. 《三峡库区珍稀植物荷叶铁线 渃、疏花水柏枝和川明参引种栽培及回归大自然研究》

(2)熊高明,1997 年 6 月. 疏花水柏枝种群生态学及繁殖研究. 中科 院植物所硕士论文 
物 56 属 93 种, 轮虫 47 属 118 种, 枝角类 31 属 74 种，桡足类 20 属 45 种。这四大类浮游动物中以轮 虫的种数最多, 约占 $13 \%$ 。库区有浮游动物 70 余 种, 常见的属有砂壳虫属 (Difflugia)、钟形虫属( Vorticella)、累枝虫属 (Epistylis) 以及轮虫 (Nematoda) 等 (中国科学院环境评价部，长江水资源保护科研所， 1996 )。

长江及主要湖泊底栖动物计有 220 多种, 其中 软体动物的瓣鰓类 73 种,腹足类 56 种, 甲壳类 7 种，水生昆虫 60 种，水栖寡毛类 13 种，多毛类 8 种， 蛭纲 3 4 种。长江干流中的底栖动物以蜻蜓目、摇 蚊幼虫、端足类、等足类等为最常见。湖泊中常见种 类有淡水壳菜 (Limnoperna lacustris) 、杜氏蛛蚌 ( $U$ nio douglasia)、背角无齿蚌 (Anodonta woodiana woodiana)、宭短褶矛蚌 (Lanceolaria grayana)、三角 帆蚌 (Hyriopsis cumingii)、褶纹冠蚌 (Cristaria plicata)、扭蚌 (Arconaia lanceolata)、黄蚬 (Corbicula fluminea)、湖螺、中国圆田螺 (Cipangopludina chinensis) 等。

水生植物是水体初级生产者, 它们的种群变化 不仅影响水体生态系统的平衡, 而且在一定程度上 与渔业产量高低有密切的关系, 对水体的净化也有 一定作用。据不完全统计，长江流域水生植物的种 类有 47 科 123 属 214 种, 其中薕类植物 4 科 5 属 6 种，双子叶植物 25 科 51 属 89 种，单子叶植物 18 科 66 属 119 种。三峡库区干流及沿岸小支流内有水 生维管束植物 40 余种, 主要有马来眼子菜( Potamogeton malainus)、苦草(Vallisneria natans)、轮叶黑 藻 (Hydrilla verticillata)、聚草 (Myriophyllum spicatum)、金鱼藻 (Ceratophyllum demersum) 等, 在干流中 种类和数量均很少, 支流中种类虽多, 但数量较少。

\subsection{2 大型水生动物 长江是我国淡水鱼类最丰} 富的河流，具有名特优鱼类资源、种质资源及水生野 生动物资源的独特优势。长江流域有鱼类 350 种， 其中纯淡水鱼类 324 种，过河口洄游鱼类 10 种，咸 淡水鱼类 16 种。值得注意的是, 长江有 142 种特有 鱼类, 其中有 112 种集中在上游江段, 中下游江段仅 有 21 种,另外 9 种则是在长江上、中和下游江段都 有分布的。现已被列为国家一级保护水生野生动物 的有白暨豚 (Lipotes vexillifer)、中华鲟 (Acipenser sinensis)、白鲟( Psephurus gladius)，二级保护动物有 江豚 ( Neophocaena phocaenoides)，达氏鲟 (Acipenser
dabryanus)、胭脂鱼(Myxocyprinus asiaticus) 等。

三峡工程对水生生物特别是鱼类的影响，一直 是我们十分关注的问题。大坝对鱼类的影响应主要 考虑:一、鱼类能否适应改变后的水文情势, 特别是 鱼类的产卵繁殖;二、是否影响了鱼类的饵料生物和 鱼类的栖息地;三、是否影响鱼类的发育，如个体大 小、性比、遗传等。以上这些问题十分复杂, 加上影 响因素很多, 影响时效上多具长期性, 有些影响可以 给出定量的评价, 多数只能给出定性的估计, 容易出 现认识差异乃至较大分歧。

\section{（1）珍稀水生动物}

白暨豚和江豚:白暨豚属于鲸目,齿鲸亚目, 淡 水豚总科, 是世界上 5 种淡水豚之一, 仅生存于长江 中下游中。江豚属齿鲸亚目中的鼠海豚科, 是一种 分布广泛的小型齿鲸。长江江豚是一个独立的淡水 亚种。白暨豚的种群数量 1986 年估计为 300 头左 右,1990 年不足 200 头, 1998 年可能还不到 100 头。 江豚 1993 年估计为 2700 头(王丁等,1998)。白暨 豚已濒临灭绝, 江豚的数量也在不断减少。造成白 暨豚和江豚数量下降的原因是多方面的, 如作为饵 料生物的鱼类资源下降, 有害渔具杀伤, 航运业影 响，水利设施建设等。由于白暨豚和江豚传统上不 生存于三峡库区, 因此三峡工程对白暨豚和江豚可 能存在的影响主要是建坝后清水下泄, 河床冲刷带 来栖息环境的改变。

中华鲟、达氏鲟和白鲟: 全世界现存的鲟形目鱼 类有 27 种和 5 亚种, 其中鲟科 25 种和 5 亚种,白鲟 科 2 种。长江中有 2 种鲟科鱼类, 中华鲟、达氏鲟; 1 种白鲟科白鲟属白鲟。中华鲟属江海洄游性鱼类， 在葛洲坝建坝前在长江上游金沙江繁殖, 建坝后在 葛洲坝下繁殖, 在海洋中育肥长大, 以海洋生活为 主。达氏鲟属于纯淡水鱼类。白鲟的洄游习性尚不 清楚。由于葛洲坝对长江的阻隔作用, 直接影响到 中华鲟的洄游, 因此对中华鲟的研究成果最多(危 起伟等, 1998; 四川省长江水产资源调查组,1988)。

根据目前的研究, 中华鲟的产卵繁殖对水温、水 位、含沙量和河床底质都有要求。由于葛洲坝的阻 隔作用, 在葛洲坝下形成了中华鲟自然产卵场。因 此,三峡工程对中华鲟的影响不在于阻隔作用。三 峡工程属于季调节水库, 将改变长江径流的年内分 配, 特别是每年 10 月开始蓄水, 下泄流量减少, 产卵 场面积缩小, 水位、水温和河床条件发生改变, 可能 
对中华鲟的产卵繁殖产生不利影响。

达氏鲟产卵场较为分散, 主要分布于长江上游 合江至金沙江下游的冒水江段，三峡库区也有分布。 达氏鲟对产卵繁殖条件的要求没有中华鲟那样严 格。重庆长寿湖曾在水库库湾试养达氏鲟获得成 功。

20 世纪 80 年代以前, 中华鲟、白鲟和达氏鲟都 是长江上游的主要经济鱼类。对中华鲟在长江中的 资源量进行估计表明 ${ }^{\circledR}$ : 从 90 年代以来，中华鲟的 资源量呈下降趋势, 1999 年成熟个体估计为 1500 尾左右。对白鲟和达氏鲟没有人作过资源评估, 80 年代以来，根据渔民误捕记录表明，长江达氏鲟和白 鲟的误捕量逐年减少，间接说明其资源量大幅度衰 退。据调查, 1997 年长江上游有 3 次误捕白鲟和 1 次误捕达氏鲟的记录,1999 年在合江江段有 1 次达 氏鲟误捕记录 ${ }^{2}$ 。葛洲坝下游自从 1984 年出现 32 尾白鲟误捕记录以来, 误捕数量逐年减少, 1995 年 以后没有误捕记录(危起伟等, 1998)。

目前三峡工程正在建设中, 尚未对 3 种鲟鱼产 生影响。但从上述 3 种鲟鱼资源量持续下降趋势的 情况来看，我们今后保护这 3 种鲟鱼面临着严峻的 局面。

胭脂鱼: 属于鲤形目胭脂鱼科, 体长随生长而变 化, 色泽鲜艳, 是著名的观赏鱼。分布于我国的闽江 和长江, 是我国也是亚洲的特有种。胭脂鱼在长江 中分布较广,历史上曾经是长江上游的重要经济鱼 类。据四川宜宾市 1958 年统计, 怅江胭脂鱼占渔获 总量的 $13 \%$ 以上, 60 年代宜宾扁窗子胭脂鱼占渔获 量的 13\%；７0 年代中期已降至 2\%。目前，只有少 量的误捕记录, 如 1997 年 1998 年, 长江上游宜 宾、沪州、重庆市分别误捕 3、2、4 尾, 葛洲坝下游误 捕 7 尾。胭脂鱼种群数量的衰退已十分明显, 这主 要是由于过度捕捞、环境污染等因素造成的，与三峡 工程无关。胭脂鱼的人工繁殖试验在 1987 年取得 成功, 有的单位已经繁育出 $F_{2}$ 代, 物种生存已没有 很大障碍。

(2) 对库区和中下游其他鱼类资源的影响

三峡工程对其他鱼类的影响主要表现在两个方 面：一是三峡库区由于淹没改变水文条件,使库区喜 欢急流环境的鱼类受到较大影响，这些鱼类大多属 长江上游特有鱼类, 在生物多样性保护上具有重要 价值。如河鲶 (Silurus meridionalis) 、长吻鮸 (Leio- cassis longirostris)、圆口铜鱼 (Coreius guichenoti)、铜 鱼 (Coreius heterodon)、鲤 (Cyprinus carpio)、吻 鮈 (Rhinogobio typus) 等适于流水环境，建库后，这些鱼 类的种群数量可能减少。而鳃亚科、鲌亚科鱼类资 源将会大增。研究表明 (中国科学院环境评价部, 长江水资源保护科研所,1996) ,三峡工程将影响到 库区分布的 40 余种特有鱼类。二是对长江 四大 家鱼”的影响。长江是“四大家鱼”的栖息繁殖地 和天然种苗基因库, 具有重要价值。这 4 种鱼, 具有 相似的产卵繁殖习性和江湖洄游的特点, 常在同一 地点产卵繁殖, 在长江干流和很多支流都有其产卵 场。产卵后, 在湖泊中育肥长大。研究表明, 这 4 种 鱼的产卵条件与水位上涨过程和水温密切相关。据 1986 年的调查 (易伯鲁等, 1988) “, 四大家鱼”在重 庆一宜昌之间有 11 个产卵场, 以忠县产卵场较大。 宜昌一城陵矶之间有 11 个产卵场，以靠近葛洲坝的 宜昌产卵场和虎牙滩产卵场规模最大。城陵矶一武 穴之间有 8 个产卵场, 以黄石和黄家镇两处规模较 大。三峡工程对库区 四大家鱼” 的影响:由于库尾 江段具备繁殖条件, 水库浮游生物将增加, 草鱼 (Ctenopharyngodon idellus)、鲢鱼 (Aristichthys nobilis) 和鳙鱼 (Hypophthalmichthys molitrix) 资源将增加。 对长江中游 四大家鱼”的影响:一方面, 水域产卵 场的规模和位置将发生变化; 另一方面, 葛洲坝下宜 昌一城陵矶江段, 如果水库调度不考虑家鱼繁殖需 要的水位上涨过程和水温要求, 家鱼繁殖将受到严 重影响, 这样将减少进入洞庭湖的家鱼数量, 影响渔 业产量。

多年监测表明 湖北监利江段 四大家鱼”的鱼 苗量呈减少的趋势，1986、1997、1998、1999 年分别 为 71.9 亿、35.87 亿、 27.47 亿和 21.54 亿尾, 说明 参加繁殖的 四大家鱼” 亲鱼数量减少, 资源衰退严 重。这给我们评价未来三峡工程对渔业的影响增加 难度和变数。

（3）对河口及近海营养物质和渔业资源的影响 埃及 ASWAN 高坝是多年调节水库，坝址年径 流量为 840 亿 $\mathrm{m}^{3}, 80$ 年代平均年入海径流量为 60 亿 $\mathrm{m}^{3}$, 因此对河口生态环境有大的影响 (黄真理,

(1)常剑波,1999 年 10 月. 长江中华鲟繁殖群体结构特征和数量变动 趋势研究. 中科院水生所博士论文

(2)中科院水生所, 《水生动物流动监测站监测工作年度报告 (1997, $1998,1999,2000) 》 。$ 
$2001)$ 。三峡水库是季调节水库, 坝址径流量只占 入海径流量的一半左右,对河口的影响主要是通过 在每年 9 10 月蓄水期和 3 5 月泄水期径流量的 变化来体现的。根据对宜昌站和大通站两个下游代 表水文站进行三峡建库前后的年内流量变化对比分 析与计算表明: 建库后坝下游的每月流量变化均在 建库前的天然流量 (最大、最小) 变幅范围内, 入海 年径流量不变。这是三峡工程与 ASWAN 高坝的一 个很大不同点。

长江河口是一个复杂多变而又敏感的地区, 影 响因子众多, 径流量仅仅是影响河口生态环境的重 要因子之一。长江河口内初级生产力的水平分布呈 河口、近海低,向外海方向升高的趋势, 最高部分在 东北部水域。整个河口地区生物资源丰富，常年调 查能遇见的浮游植物有 51 种, 浮游动物有 47 种, 底 栖生物中多毛类 40 种, 软体动物 19 种, 甲壳动物 7 种，棘皮动物 4 种，鱼类 3 种，腔肠动物 1 种。此外， 该水域具有资源意义的动物共有 69 种, 分别是鱼类 40 种、虾类 13 种、蟹类 6 种、头足类 5 种、细肋蕾螺 (Gemmula deshayesii)、微点舌片鳃 (Armina babai)、 毛蚶 (Scapharca subcrenata)、马粪海胆 (Hemicentrotus pulcherrimus)、口虾蛄各 1 种。在所捕捞的资源中， 主要以小、杂鱼为主。

坝址以上水体中氮、磷等营养物质贡献量占河 口的 $20 \% \sim 30 \%$, 进入河口的营养物质主要来源于 中下游支流和通江湖泊 (中国科学院环境评价部， 长江水资源保护研究所,1996)。长江口及其近海 是我国主要的渔场。由于鱼类的生活习性不同, 径 流量的变化对有些种有利, 对有些种不利。如对中 华线螯蟹 (Eriocheir sinensis) 产卵场可能有不利影 响;对凤鲚 (Coilia mystus)、银鱼和鲥鱼 (Macrura reevesi) 等资源可能有利; 对刀鲚 (Coilia ectens) 和梅 童鱼等则产生不利影响。总之, 目前对这种影响的 机理尚不清楚, 很难作出明确的评价或估计, 更难以 作出定量分析,需要加强研究和监测。

\section{3 三峡工程的生物多样性保护措施和进展}

3.1 建立陆生动植物和水生生物监测站网，加强对 受影响物种的保护生物学研究

根据三峡工程环境影响报告书和初步设计 (环 境保护篇）,从1996 年起, 我们组建了一个庞大的跨 地区、跨部门的三峡工程生态与环境监测网络, 对三 峡工程所涉及的生态与环境因子进行全过程的跟踪
监测, 为改善库区及相关区域的生态环境提供技术 保障,也为未来进行环境影响回顾性评价积累数据。 其中包括陆生动植物和水生生物监测, 并组织了相 应的保护生物学研究, 取得了丰富的监测和研究成 果。

1) 陆生动植物:由林业部门负责组建了陆生动 植物监测重点站, 对三峡库区的陆生动植物进行调 查和监测。1996 年 1999 年, 完成了对三峡库区的 陆生动植物的全面本底调查和研究。由中国科学院 植物所负责组建了一个陆生植物观测实验站, 监测 三峡库区陆生生物多样性的动态变化, 利用生物多 样性对环境的反馈作用来评估环境的变化。

对库区受影响的植物进行迁移和繁殖等保护生 物学研究。如:已完成库区珍稀植物 30 种及库区主 要优势植物 73 种的迁地保存; 对荷叶铁线偋和疏花 水柏枝开展了大量的移植、繁殖和生态学研究工作, 取得了一系列保护性试验研究成果(徐惠珠等, 1998 ; 吴金清等,1998; 沈泽昊等,1999)。除了迁地 保护外, 我们已完成对荷叶铁线䓲、疏花水柏枝和川 明参大规模人工引种繁殖后返回大自然的研究。在 环境相似或相近的地方, 通过恢复这些物种及其群 落达到减少三峡工程不利影响的目的。从 1995 年 ～1998 年, 已完成对首先受淹的湖北 4 县 44 株古 树的研究和保护工作。

2 ) 水生生物:由渔业部门和中国科学院水生所 分别承担渔业资源与渔业环境监测站和珍稀水生动 物流动监测站, 及时掌握珍稀鱼类、渔业资源和渔业 环境的变动趋势。另外, 中国科学院海洋所牵头组 建了三峡工程河口观测实验站, 对河口及近海水文、 水化学、生物环境要素、渔业资源量和结构、河口生 态系统结构和功能等进行定位观测研究。

有针对性地加强了对鱼类保护生物学的研究。 如基本弄清了中华鲟在葛洲坝下的资源量、产卵场 和产卵规模。采用标记放流方法, 对中华鲟人工繁 殖放流的效果进行了初步评价。开展对上游特有鱼 类保护方法的研究, 我们建议选择长江上游支流 赤水河作为保护长江上游珍稀特有鱼类保护 区, 使长江上有一条完整的支流能作为鱼类的产卵 繁殖和栖息地 ${ }^{(1)}$ 。由于白暨豚的数量已十分少, 保

(1)中科院水生生物研究所, 《长江上游特有鱼类保护方法研究报 告》,1998 年 6 月。 
护工作转变为以迁地保护为主, 为此, 组织开展捕豚 工作。除此之外，经济鱼类特别是 四大家鱼”也是 我们关注的重点, 当前急需开展跨学科攻关, 研究其 产卵繁殖与水力学条件的关系, 即笔者提出并倡导 的 四大家鱼”生态水力学问题, 为今后三峡水库运 行调度制造人造洪峰满足家鱼繁殖提供技术支持。

\section{2 建立自然保护区和保护点}

对生物多样性最有效的保护措施是建立自然保 护区，保护物种及其栖息地。配合三峡工程建设，国 家将规划建立一系列保护区，保护受工程影响的陆 生和水生生物 (表 2)。对陆生动植物保护来说, 由 于受三峡工程淹没和移民搬迁直接影响的低海拔地 区已没有建设自然保护区的条件，规划中的保护区 主要集中在未受工程影响的宜昌大老岭、兴山龙门 河高山地区。疏花水柏枝属于全部受淹没影响的物 种, 需要重新调整原规划设计中自然保护的对策措 施，进行迁地保护，在生境相似的地方迁移栽培，并 研究今后在三峡库区 $30 \mathrm{~m}$ 消落带引种栽培、改善消 落带景观的可能性。荷叶铁线藓等受影响的物种和 古大树种，因分布分散，只能建立保护点。

对于鱼类等水生生物, 主要建立 5 个长江自然 半自然保护区，保护其栖息地。在长江上建立珍稀 鱼类自然保护区难度很大，因为长江是我国主要内 陆通航河流，两岸人类活动也很频繁，保护区特别是 核心区仍然不可避免受到人类活动的干扰。加之目 前长江上对渔民作业的管理力度还不够，在保护区 以及保护区周边非法作业现象仍然时有发生，对渔 业资源和鱼类栖息环境的破坏较大，从而影响保护 区的保护效果。另外，国家正积极筹备向家坝、溪洛 渡等大型水利枢纽工程。规划中的合江一屏山特有 鱼类保护区位于上述工程建设范围内, 与向家坝、溪 洛渡等长江干流梯级开发项目发生矛盾, 有关部门 正在组织论证。鉴于保护长江上游特有鱼类的工作 十分重要，长江干流梯级开发的目标已定，应在长江 上游选择 $1 \sim 2$ 条支流不进行开发利用而作为自然 保护区长期存在, 最大限度地保护长江上游特有鱼 类。当前, 应积极推动实现中国科学院水生所专家 多年论证提出的在长江上游支流赤水河建立特有鱼 类保护区的方案，统筹考虑向家坝、溪洛渡等水电工 程与三峡工程的生态保护工作, 达到长江干流梯级 开发和上游特有鱼类保护相协调的目标。
中华鲟、达氏鲟和胭脂鱼的人工繁殖放流技术 已比较完善。特别是中华鲟的人工繁殖放流, 作为 葛洲坝修建后增殖中华鲟资源的主要手段之一，从 1984 年已开始进行。据肖慧等 (1999) 报道, 从 1983 1998 年放流中华鲟仔鱼 425.8 万尾, 放流 3 $\sim 5 \mathrm{~g}$ 幼鲟 6.28 万尾。对达氏鲟、胭脂鱼也进行过 放流。根据三峡工程的初步设计安排, 将投资在重 庆、万县、宜昌建设 3 个新的人工繁殖放流站, 对中 华鲟、白鲟、达氏鲟、胭脂鱼等珍稀鱼类进行人工增 值放流。总结以往经验和教训, 这种完全按照计划 经济运作的建设方式, 将使国家背上沉重的包袱, 既 不利于充分发挥已有人工繁殖放流研究机构的作 用，也不利于提高放流资金的使用效益。

在实施三峡工程的人工增值放流时,需要借鉴 国内外的经验特别是已开展的中华鲟人工繁殖放流 的经验和教训: 一是在进行人工繁殖放流的同时, 需 要同时进行放流效果的评估研究工作。葛洲坝工程 放流了 400 多万尾, 但对其增殖效果是不清楚的, 即 放流的中华鲟有多少进入海里育肥? 又有多少回到 长江? 从目前我们对中华鲟进行标记放流的初步结 果来看, 效果并不乐观。二是用于人工繁殖放流的 中华鲟亲鱼捕捞量过大。据不完全统计 ( 肖慧等, 1999）,1984１998 年用于科研和放流的中华鲟亲 鱼捕捞量为 663 尾 (雌鱼 455 尾, 雄鱼 208 尾), 实际 用于人工催产的雌鱼仅为 107 尾。用于科研和放流 的中华鲟亲鱼捕捞量大大超过实际需要, 无形中造 成了对资源的破坏, 这个问题应引起渔业主管部门 和科研人员的重视。三是要借鉴国内外的管理经 验，引入市场竞争机制，提高用于放流资金的使用效 益。四是进一步完善人工繁殖放流技术，包括非致 死取卵和产后亲鱼恢复技术、白鲟的人工繁殖技术 等等。

建议在维持初步设计中人工繁殖放流目标不变 的前提下,利用 3 个人工繁殖放流站的建设经费建 立 珍稀鱼类人工繁殖放流基金”, 运用市场经济机 制进行人工繁殖放流。同时, 加强珍稀鱼类人工繁 殖放流技术的研究。

3.4 合理制定移民安置规划, 调整库区产业结构， 发展生态农业

三峡库区最终移民规模将达到 113 万人，这将 加剧本已紧张的人地矛盾和对生态环境的压力。因 此, 只有采取一系列有效措施, 才能扩大移民环境容 
表 2 三峡工程自然保护区一览表

Table 2 List of nature reserves for the Three Gorges Project area

\begin{tabular}{|c|c|c|c|c|}
\hline & $\begin{array}{c}\text { 保护区名称 } \\
\text { Name of nature reserve }\end{array}$ & $\begin{array}{l}\text { 主要保护目标 } \\
\text { Protected targets }\end{array}$ & $\begin{array}{l}\text { 保护区面积或长度 } \\
\text { Protected area/length }\end{array}$ & $\begin{array}{c}\text { 保护进展 } \\
\text { Recent progress in conservation }\end{array}$ \\
\hline \multirow{7}{*}{$\begin{array}{l}\text { 陆 } \\
\text { 生 } \\
\text { 生 } \\
\text { 物 }\end{array}$} & $\begin{array}{l}\text { 湖北宜昌大老岭植物多样 } \\
\text { 性保护区 }\end{array}$ & $\begin{array}{l}\text { 亚热带山地天然森林生态系 } \\
\text { 统珍稀古大树种,库区部分 } \\
\text { 珍稀濒危物种迁入保护区 }\end{array}$ & $\begin{array}{l}5936 \mathrm{hm}^{2} \text { (核心区 : } 1530 \\
\mathrm{hm}^{2} \text { ) }\end{array}$ & $\begin{array}{l}1992 \text { 年被批准为国家森林公园。1995 } \\
\text { 年开始植物多样性保护工程设计和建 } \\
\text { 设, 1999 年 } 6 \text { 月完成。已完成保护区植 } \\
\text { 物名录。 }\end{array}$ \\
\hline & $\begin{array}{l}\text { 湖北兴山龙门河常绿阔叶 } \\
\text { 林保护区 }\end{array}$ & $\begin{array}{l}\text { 亚热带常绿针叶林、自然植被 } \\
\text { 带谱、植物物种多样性和珍稀 } \\
\text { 植物群落 }\end{array}$ & $\begin{array}{l}4644 \mathrm{hm}^{2} \text { ( 核 心区: } 873 \\
\mathrm{hm}^{2} \text { ) }\end{array}$ & 已完成常绿阔叶林保护工程设计 \\
\hline & $\begin{array}{l}\text { 重庆巫山小三峡景观生态 } \\
\text { 保护区 }\end{array}$ & $\begin{array}{l}\text { 自然景观、生态系统和环境、 } \\
\text { 文物和文化遗迹 }\end{array}$ & $2000 \mathrm{hm}^{2}$ & $\begin{array}{l}\text { 已是长江上的著名旅游景区, 受到严格 } \\
\text { 保护。 }\end{array}$ \\
\hline & $\begin{array}{l}\text { 重庆万州新乡荷叶铁线蕨 } \\
\text { 保护点 }\end{array}$ & 原产地和群落 & 待定 & 完成人工繁殖和迁地保存 \\
\hline & $\begin{array}{l}\text { 湖北䄰归疏花水柏枝保护 } \\
\text { 点 }\end{array}$ & 进行迁地保护 & 待定 & 完成人工繁殖和迁地保存 \\
\hline & 湖北宜昌川明参保护点 & 原产地和群落 & 待定 & 完成人工繁殖和迁地保存 \\
\hline & 库区古大树种单株保护点 & $\begin{array}{l}\text { 古大树种及环境 (总计 } 199 \\
\text { 株) }\end{array}$ & 单株 & $\begin{array}{l}1998 \text { 年已完成对湖北库区 } 44 \text { 株的保护 } \\
\text { 工程 }\end{array}$ \\
\hline \multirow{5}{*}{$\begin{array}{l}\text { 水 } \\
\text { 生 } \\
\text { 生 } \\
\text { 物 }\end{array}$} & $\begin{array}{l}\text { 长江上游珍稀特有鱼类自 } \\
\text { 然保护区 }\end{array}$ & $\begin{array}{l}\text { 白鲟、达氏鲟、胭脂鱼，长江特 } \\
\text { 有鱼类 }\end{array}$ & 250 km ( 合江 - 屏山 ) & 1999 年被批准为国家级自然保护区 \\
\hline & $\begin{array}{l}\text { 葛洲坝下游江段珍稀鱼类 } \\
\text { 自然保护区 }\end{array}$ & $\begin{array}{l}\text { 中华鲟、白鲟、胭脂鱼、“四大 } \\
\text { 家鱼” }\end{array}$ & $80 \mathrm{~km}$ (葛洲坝 - 枝江) & $\begin{array}{l}1996 \text { 年被批准为湖北省省级自然保护 } \\
\text { 区 }\end{array}$ \\
\hline & $\begin{array}{l}\text { 长江新螺江段白暨豚自然 } \\
\text { 保护区 }\end{array}$ & 白暨豚、江豚 & $135 \mathrm{~km}$ (螺山 - 新滩口) & 1992 年被批准为国家级自然保护区 \\
\hline & $\begin{array}{l}\text { 长江口中华鲟和白鲟幼鱼 } \\
\text { 自然保护区 }\end{array}$ & 中华鲟和白鲟幼鱼 & $21 \mathrm{~km}$ (崇明岛东) & 将被批准为上海市市级自然保护区 \\
\hline & 天鹅洲半自然保护区 & 白暨豚和江豚 & $\begin{array}{l}21 \mathrm{~km} \text { (长江故道) } \\
89 \mathrm{~km} \text { (石首江段) }\end{array}$ & 1992 年被批准为国家级自然保护区 \\
\hline
\end{tabular}

量, 减轻移民安置对生物多样性的影响。一是加强 与移民安置规划部门的协调，避免对古大树种和珍 稀植物群落的影响。二是调整库区产业结构, 对污 染大、效益低的企业，实行关停并转。三是大力发展 生态农业, 利用库区气候特点,改变单一的农业种植 结构。四是改变库区农村以烧柴为主的农村能源结 构,推广沼气和节柴灶,减轻对木材的需求和对植被 的破坏。五是实行移民外迁沿海各省, 减轻库区人 地矛盾，缓解生态压力。

3.5 实施天然林保护和退耕还林 (草)工程, 保护 库区整体生态环境

三峡库区及长江上游属于西部大开发中实施生 态保护的重点地区。从 2000 年起, 国家将利用 10 年左右的时间, 在库区所有县 (市、区) 及长江上游 地区全面停止天然林采伐，对 $25^{\circ}$ 以上的坡耕地全 部实行退耕还林, 对荒山荒坡进行植树造林。这将 根本改善三峡库区及长江上游的生态环境, 为三峡 工程的蓄水发电和长期运行创造良好的生态环境条
件。

3.6 加强库区生物的管理, 提高当地居民的保护意 识

三峡库区属于传统上的贫困地区, 经济相对落 后，对森林的过度依赖和砍伐对野生动植物的破坏 较大, 因此, 需要加强对陆生动植物的管理, 特别是 物种栖息地的保护。长江珍稀鱼类和渔业资源在我 国占有十分主要的地位, 但与海洋渔业相比, 管理上 还存在明显差距, 电鱼、毒鱼、炸鱼和密眼网具大量 捕捞幼鱼的行为依然存在, 再加上渔业环境的恶化, 对资源的损害极大, 需要加强对渔业资源和水生野 生动物的管理。自然保护事业的发展离不开当地居 民的支持，提高当地居民的环境保护意识，建立良好 机制，争取当地居民的积极参与是自然保护工作的 重要环节。

\section{4 结语}

三峡工程对生物多样性的影响,一直是三峡工 程环境保护的一个重点。对受影响的物种, 不仅进 
行原地保护和迁地保护, 还开展相应的保护生物学 研究。对有争议或有潜在、长期影响的问题开展长 期的观测或监测研究。过去, 我们主要从物种层面 来开展工作，重点是珍稀、特有物种，近年也正在积 极开展疏花水柏枝和荷叶铁线䕬遗传多样性 ${ }^{\circledR}$ 、中 华鲟遗传多样性等项研究 (朱滨, 常剑波, 1999; 朱 滨等, 1999) ,为保护物种遗传多样性提供科学依 据。

三峡工程对生态与环境保护的重视, 在中国水 电工程建设史上是前所未有的，在有关部门的支持 下,已经和正在开展大量的保护工作。以往也没有 成熟的经验可以借鉴,还需要在实践中不断摸索前 进。三峡工程对生物多样性的影响, 涉及面广, 涉及 的学科很多, 有些影响是短期的, 有些是长期的, 有 些是显见的,有些是潜在的。影响因素十分复杂，人 们往往习惯于把不利的变化统统算在三峡工程的身 上,夸大工程的不利影响 忽视其他因素的影响。比 如，这些年来长江珍稀水生野生动物和渔业资源的 衰退十分严重, 这本身并非三峡工程引起的,也不完 全是葛洲坝等其他水利工程引起的，还应包括管理 工作不到位等众多非工程因素的影响。因此,三峡 工程的生态保护, 单靠三峡工程自身的努力是远远 不够的，必须有行业主管部门、地方政府、当地居民 和其他方面的共同参与，把资金真正用到实现保护 目标上,才能使减少对生态环境不利影响的各项措 施真正落到实处，发挥长久的效益。

长江上游是我国生物多样性最丰富的地区之 一。当前国家正在进行西部大开发,包括长江上游 在内的西部地区丰富的水电资源将逐步进行开发和 利用。因此, 应该把三峡工程对生物多样性的保护 工作, 与整个长江上游梯级开发规划一起进行综合 研究。在科学评价不同河段或支流及其汇水区的水 力资源开发价值和生物多样性价值的基础上, 对开 发和保护问题进行综合规划, 统筹安排, 开发和保护 并重, 以保障长江上游地区的经济可持续发展, 生物 多样性得到有效保护。

致谢 对中国科学院水生所常剑波研究员, 中国科 学院植物所谢宗强研究员、熊高明先生, 中国科学院 海洋所沈志良研究员表示感谢。

\section{参考文献}

长江水系渔业资源调查协作组, 1990。长江水系渔业资源. 北京: 海洋出版社
常剑波, 黄真理, 曹文宣, 1998. 葛洲坝工程救鱼问题的争论 和启示. 见: 黄真理等 (主编), 21 世纪长江大型水利工 程中的生态与环境保护. 北京: 中国环境科学出版社

陈伟烈, 张喜群, 梁松筠, 金义兴, 杨启修, 1994. 三峡库区的 植物与复合农业生态系统. 北京: 科学出版社

国家环境保护总局. 长江三峡工程生态与环境监测公报 (1997 2000)

黄宏文, 2000. 荷叶铁线蕨等位酶分析初步研究. 武汉植物 学研究, 18(4) : 347 350

黄真理, 2001. 阿斯旺高坝的生态环境问题. 长江流域资源 与环境, $10(1): 82 \sim 88$

蒋志刚, 马克平, 韩兴国 (主编), 1997. 保护生物学. 杭州: 浙 江科学技术出版社

钱迎倩, 马克平 (主编), 1994. 生物多样性研究的原理与方 法. 北京: 中国科学技术出版社

沈泽吴, 金义兴, 吴金清, 赵子恩, 1999. 三峡库区两种特有 植物天然生境与迁地生境土壤特征的比较. 武汉植物 学研究, 17(1): 46 52

四川省长江水产资源调查组, 1980. 长江鲟鱼类鱼类生物学 及人工繁殖研究. 成都: 四川科学技术出版社

王丁, 张先峰, 刘仁俊, 1998. 中国长江白暨豚、江豚保护的 现状及其末来. 见: 黄真理等 (主编), 21 世纪长江大型 水利工程中的生态与环境保护. 北京: 中国环境科学出 版社

危起伟, 杨德国, 柯福恩, 1998. 长江鲟鱼类的保护策略. 见: 黄真理等(主编), 21 世纪长江大型水利工程中的生态 与环境保护. 北京: 中国环境科学出版社

吴金清, 赵子恩, 金义兴, 沈泽昊, 1998。三峡库区特有植物 疏花水柏枝的调查研究. 武汉植物学研究, 16(2): 111 $\sim 116$

肖慧, 常剑波, 刘勇, 1999. 中华鲟人工繁殖放流现状评价. 水生生物学报, 23(6):572 576

肖文发, 李建文, 于长青等, 2000. 长江三峡库区陆生动植物 生态. 重庆: 西南师范大学出版社

谢宗强, 马克平, 1998. 三峡工程与三峡库区陆生植物多样 性保护. 见: 黄真理等 (主编), 21 世纪长江大型水利工 程中的生态与环境保护. 北京: 中国环境科学出版社

谢宗强, 陈伟烈, 1999. 三峡库区药用植物资源特征及其保 护对策. 自然资源学报, 14(3):232 237

徐惠珠, 金义兴, 江明喜, 吴金清, 1998。 三峡库区珍稀特有 植物荷叶铁线蕨的狍子繁殖. 长江流域资源与环境, 7 (3) : $237 \sim 241$

杨星科主编, 1997. 长江三峡库区昆虫 (上、下). 重庆: 重庆 出版社,

易伯鲁, 余志堂, 梁秩榮等, 1988. 葛洲坝水利枢纽与长江四 大家鱼. 武汉: 湖北科学技术出版社

中国科学院环境评价部, 长江水资源保护科研所, 1996. 长 江三峡水利枢纽环境影响报告书(简写本). 北京: 科学 出版社

朱滨, 常剑波, 1999. 微卫星 DNA 及其在鱼类中的运用. 水 生生物学报, 23(6):721 728

朱滨, 常剑波, 谭细畅, 虞功亮, 肖从学, 吴志强, 1999. 湖鲟 微卫星 DNA 引物应用于中华鲟亲子关系分析的初步研 究. 水生生物学报, 23(6):547 553

(责任审稿人 谢宗强, 常剑波; 责任编辑 : 孙大川,闻文杰)
(1)中科院武汉植物所，《三峡库区珍稀植物荷叶铁线颜、疏花水柏枝 和川明参引种栽培及回归大自然研究》2001 年 4 月 